\title{
The effect of the Problem Based Service Eco Learning (PBSEcoL) model on student environmental concern attitudes
}

\author{
Sumarmi* \\ Universitas Negeri Malang, Malang, Indonesia
}

\begin{abstract}
This research aims to determine the effect of the Problem Based Service Eco Learning (PBSEcoL) model on disaster awareness and environmental concern attitudes. The research design is a quasi-experiment. The research subjects were students of the Department of Geography and Faculty of Social Sciences in the State University of Malang. The sample was taken from class A and class B with homogenous features in the Environmental Geography course. The data was collected using an attitude questionnaire and then analyzed by comparing the questionnaire gain score of the control and experimental groups. The result showed that the PBSEcoL model had an effect on students' environmental concern attitudes with an average value in the experimental group of 86.53 , while the control group was 75.94. The research is expected to provide information about the application and benefits of the PBSEcoL model in learning geography for students.
\end{abstract}

\section{INTRODUCTION}

Problem Based Service Eco Learning (PBSEcoL) integrated the educational process and direct community service. The learning objective is to improve critical thinking, analytical, and responsibility. The program is used to develop students' active participation in services and other activities related to the environment (Ardani et al. 2016; Irfianti et al. 2016). Students can apply their knowledge from the classroom to solve problems in real life.

Lecturers can use PBSEcoL to integrate learning with real-life by applying knowledge to answer students' problems while participating in learning in the classroom. PBSEcoL is a learning model that is fully integrated with services to the community related to the environment. PBSEcoL can be used by the lecturer based on the relevant field of study in the classroom. Using PBSEcoL can accelerate understanding of social science or other fields of study. Through PBSEcoL, students can construct new knowledge, research the projects' problems, make decisions related to the project and help and serve to solve environmental problems and mitigate disasters in their surroundings. The PBSEcoL is important to be implemented in learning because 1) it can connect education with society's needs, (2) it is able to develop an in-depth understanding with a learning process that refers to pedagogy through active learning, provide feedback to experts, students and the community, collaboration, and cognitive apprenticeships (lecturers and students can discuss generalizations, theories, principles, transfer of knowledge between theories and practice and analyze them), (3) PBSEcoL enriches multidisciplinary discussions. Environmental and disaster problems are handled by one discipline and this discipline must instead collaborate with various disciplines (Sumarmi et al. 2020).

Learning with Problem Based Service learning has risks, such as real problems that students have not mastered related to the environment and disasters and do not match the community's needs.

\footnotetext{
*Corresponding author: sumarmi.fis@um.ac.id
} 
The advantage of Problem Based Service learning is that students have a comprehensive and strong understanding of learning topics in the classroom that are closely related to the community's needs. Students can directly see the environmental problems that occur and mitigate disasters based on existing geographical conditions.

\section{METHOD}

The research is a quantitative study with a quasi-experimental research design. The subjects were students of Environmental Geography course in Geography programs and Social Science faculty in the State University of Malang. The research subjects were selected as two classes with homogeneous features: class A as the Experiment group and class B as the control group. Both classes have the same number of students, 31 people, and are taught by the same teacher. The research instrument used questionnaires, observation, and documentation. Environmental concern attitude data is compiled based on environmental concern indicators and is measured using a questionnaire with 20 questions. Observations are made to observe student and lecturer activities during the learning process and are carried out directly. Documentation was used to support the research, such as data and photos. The research was analyzed using the t-test (independent sample t-test) with SPSS for windows 21.00 to find the gain score (the difference between the pretest and posttest scores).

\section{RESULT}

The students' environmental concern attitude was obtained from the pre-test and post-test scores in the control and experimental groups to obtain the gain score. The result of environmental concern attitude was 13.11 for the control group and 23.43 for the experimental group. The result showed that the gain score in the experimental class using the PBSEcoL model was higher than the control class. Comparing the values between the pre-test, post-test, and gain scores of the environmental concern attitude of the control and the experimental group can be seen in the following table.

Table 1. The Average Pretest, Posttest, and Gain Score for the Control and Experimental Group.

\begin{tabular}{llll}
\hline Group & Pretest & Posttest & Gain Score \\
\hline Control & 62,83 & 75.53 & 13.11 \\
Experimental & 63,10 & 86,53 & 23,43 \\
\hline
\end{tabular}

Table 1 showed an increase in the average pre-test and post-test scores in the control and experimental groups. Furthermore, the gain score in the experimental group was higher than the control group which was shown in the table was the increasing amount for the experimental group after treatment using the PBSEcoL model. This study supports the results that Ardianti (2017) and Kasi, Sumarmi and Astina (2018), stated in that the average value of environmental concern attitudes with the PBSEcoL model is higher than the average value using conventional models.

Students get personal, interpersonal, social and academic benefits in participating in Problem Based Service Learning (Kim \& Lee 2018). Students' academic and leadership abilities have also improved. Through PBSEcoL learning, students have a high response to learning, apply concepts that have been learned in society, increase students' interest about social issues that occur, and build critical thinking skills and communication skills. Using PBSEcoL learning, students can see something more deeply to describe or explain the learning process and serving experience.

The implementation of PBSEcoL in the classroom consists of 4 stages: design to action, ecoaction, reflection, and demonstration/celebration. (1) Design to Preparation is a preparatory step 
that explores and analyzes problems in the environment through direct observation, conducting interviews, and extracting information from various sources from books, printed media, and electronic media, and developing a suitable program. (2) Eco-Action is a real activity to implement environmental improvement programs. (3) Reflection is an activity to review the implementation, program implementation success and the obstacles in implementing the environmental problem improvement program. (4) Demonstration/celebration is a step to submit reports, articles and videos made for learning or community implementation and achievement (Sumarmi 2012; Sumarmi et al. 2020).

The learning has objectives to be achieved, so the assessment needs to be carried out based on the objectives and type of learning. Besides learning the topic in PBSEcoL, students also learn to serve immediately, so an authentic assessment is critical. Assessment can be obtained by conducting interviews, observing student group work practices and individual work, checking students' activities in a logbook, making product results and collecting data and articles presented in newspapers or journals.

J. Eyler and D.E. Giles Jr. (1999) stated that PBSEcoL provides positive benefits for the personal development of students, including helping personal development both personally and inter-personally, understanding and applying knowledge, developing critical thinking, changing ways of thinking and perspectives and forming a strong personal character as citizens to environmental problems. Also, PBSEcoL has a strong influence on character building (soft skills) such as caring, creative and critical thinking, leadership, building teamwork and communication skills. In the PBSEcoL method, students learn through service actions to solve environmental problems and serve the partner communities. Real situations and conditions in society and society are seen as real classrooms for learning through real experiences dealing with problems. It can also be said that the real situation and conditions in society are the "wisest teachers" that teach and develop intellectual-academic individuals.

Individual success is determined by well-scheduled activities to shape the attitude. This study seeks to discuss problem-based service learning-based learning strategies to respond to the problems previously discussed (Kolb 1984). Through PBSEcoL, there is a relationship between academic matters learned in school and activities to serve the community that can be realized step by step to increase environmental concern. Doing PBSEcoL in the community, students used their interest to solve social problems such as exploring and providing solutions to social problems (Muhaimin 2015). Students also identify environmental problems and solve environmental problems either individually or in groups or discuss possible disasters in their respective areas based on geographic conditions.

Students can implement PBSEcoL through the 'one man one tree' program around the campus, on the roadside, on the riverbank, in city parks and other places in areas with dry geographical conditions. Students must also remain responsible for maintaining these plants. The activity guides students to practice mindset shift about academics in the classroom and used it to solve environmental problems to increase the environmental concern (Sumarmi 2014). The changes can affect subsequent activities (Mamat et al. 2019). To study well in class and society, students need to have the right learning attitude. Students who are serious about learning will show qualities such as volunteering, joy, a love of learning, self-reflection, not being selfish and being honest.

\section{CONCLUSION}

Educational institutions have the responsibility to solve environmental problems and disasters that exist in Indonesia. It is necessary to increase student knowledge, skills, and environmental concern attitude to reduce vulnerability and maintain the existing ecosystem in Indonesia. This can only be established through geography education by applying the PBSEcoL model. 


\section{REFERENCES}

Ardani, A., Utaya, S. and Budijanto, B. (2016) 'Pengaruh Model Pembelajaran Service-Learning terhadap Hasil Belajar Geografi SMA (The Effect of Service-Learning Learning Models on Geography Learning Outcomes in Senior High Schools)', Jurnal Pendidikan: Teori, Penelitian, dan Pengembangan, 1(11), pp. 2145-2151. Available at: https://doi.org/10.17977/jp.v1i11.7977.

Irfianti, M. D., Khanafiyah, S. and Astuti, B. (2016) 'Perkembangan Karakter Peduli Lingkungan Melalui Model Experiential Learning (Development of Environmental Concern through the Experiential Learning Model)', UPEJ Unnes Physics Education Journal, 5(3), pp. 72-79. Available at: https://doi.org/10.15294/upej.v5i3.13768.

Kasi, K., Sumarmi and Astina, K. (2018) 'Pengaruh model pembelajaran service learning terhadap sikap peduli lingkungan', Jurnal Pendidikan Teori, Penelitian, dan Pengembangan.

Kim, E. and Lee, Y.-J. (2018) 'Serve as you learn: Problem-based service-learning integrated into a product innovation and management class'.

Kolb, D. A. (1984) 'Experiential Learning: Experience as The Source of Learning and Development', Prentice Hall, Inc. doi: 10.1016/B978-0-7506-7223-8.50017-4.

Mamat, M. et al. (2019) 'Service-learning in Malaysia: Practice and implementation in four public universities', International Journal of Civil Engineering and Technology, 10(4), pp. 1682-1691.

Muhaimin (2015) 'Membangun Kecerdasan Ekologis Model Pendidikan untuk Meningkatkan Kompetensi Ekologis', 18(2), pp. 29-43. Available at: https://doi.org/10.7233/ijcf.2018.18.2.029.

Sumarmi (2012) Model-Model Pembelajaran Geografi (Geography Learning Models). Yogjakarta: Aditya Media. Yogyakarta: Aditya Media.

Sumarmi (2014) Pengelolaan Lingkungan Berbasis Kearifan lokal (Environmental Management Based on Local Wisdom). Yogyakarta: Aditya Media.

Sumarmi et al. (2020) 'Problem-based service learning's effect on environmental concern and ability to write scientific papers', International Journal of Instruction. doi: 10.29333/iji.2020.13411a. 